\title{
Production of dengue 2 envelope domain III in plant using CPMV - based vector system
}

\author{
Lívia Érika Carlos Marques*, Bruno Bezerra da Silva, llana Carneiro Lisboa Magalhães, \\ Márcia Maria Marques Mendes, Lia Magalhães de Almeida, Maria Izabel Florindo Guedes \\ From 5th Congress of the Brazilian Biotechnology Society (SBBIOTEC) \\ Florianópolis, Brazil. 10-14 November 2013
}

\section{Background}

The envelope protein (E protein) of dengue virus is responsible for binding the virus to the host cell. This protein is considered an important immunogen for neutralization of the virus, the only able to induce the production of neutralizing antibodies [1]. The aim of this study was to use the Cowpea Mosaic Virus (CPMV) as a vector to express, on cowpea plants, Vigna unguiculata L. (Walp) the gene fragment that encodes for domain III of the $E$ protein of dengue 2 virus.

\section{Methods}

The cloning of inserts in non commercial plasmid (NCP) specific sites containing the RNA-2 of CPMV, its subsequent introduction into competent cells of Escherichia coli (DH10B) and the purification of these plasmids from the transformed cells was made through conventional molecular biology techniques. The chimerical virus was inoculated on cowpea plants, and the symptomatic leaves were processed for further purification of the recombinant protein. The protein was purified by a precipitation process described by Florindo et al. (2002) [2].

\section{Results and conclusions}

The SDS-PAGE electrophoretic profile of EDIII protein revealed the migration of a protein fraction having a molecular mass between 45 and $66 \mathrm{kDa}$ which was then recognized by specific anti-dengue antibodies by immunoblotting assay. The study shows that this expression system based on CPMV allows the production of recombinant protein maintaining its antigenic characteristics and demonstrates the potential of this platform for the transient production of proteins in plants.
Acknowledgements

Capes and CNPq for financial support.

Published: 1 October 2014

\section{References}

1. Saejung W, Fujiyama K, Takasaki T, Ito M, Hori K, Malasit P, Hori K, Malasit P, Watanabe $Y$, Kurane I, Seki T: Production of dengue 2 envelope domain III in plant using TMV-based vector system. Vaccine 2007, 25(36):6646-6654.

2. Florindo Ml, Aragão MD, Silva AD, Otoch ML, Melo D, Lima JAA, Lima MG: Immune response induced in mice oral immunization with cowpea severe mosaic virus. Brazilian Journal of Medical and Biological Research 2002, 35(7):827-835.

\section{doi:10.1186/1753-6561-8-S4-P80}

Cite this article as: Carlos Marques et al:: Production of dengue 2

envelope domain III in plant using CPMV - based vector system. BMC Proceedings 2014 8(Suppl 4):P80.
Submit your next manuscript to BioMed Central and take full advantage of:

- Convenient online submission

- Thorough peer review

- No space constraints or color figure charges

- Immediate publication on acceptance

- Inclusion in PubMed, CAS, Scopus and Google Scholar

- Research which is freely available for redistribution
() Biomed Central 